DOI 10.31651/2524-2660-2018-14-53-59

ORCID 0000-0002-4257-1528

\title{
MIPOВСЬКА Mapiona,
}

доктор наук гуманістичних в галузі педагогіки, ад’юнкт (помічник професора), керівник департатменту праці соціальної та публічного здоров'я,

Університет ім. Яна Диугоша в Ченстохові (Республіка Польща) e-mail: mmirowska@interia.pl

УДК: 364.442.2:044.14

\section{РИЗИКИ ПЕРЕРИВАННЯ СТУДЕНТОМ ОСВІТНЬОГО ПРОЦЕСУ: ОЦІНЮВАННЯ НА РІВНІ КОРИСТУВАЧА ОСВІТНЬОї ПОСАУГИ}

На підставі аналізу як окремих випадків, так $і$ статистичних даних трьох закладів вишої освіти шодо відрахування чи переведення студента на вечірню/заочну форми навчання було встановлено, шо навчання студента $у$ закладі вищої освіти є нестабільним проиесом, який несе у собі численні ситуативні ризики незавершення процесу навчання. Ситуативна обумовленість такого ризику пов'язана пери за все із фінансовою несамостійністю студента, його особливостяли вікового розвитку, де пріоритетом виступає зорієнтованість на перехід в самостійне життя при несформованих для иього особистісних та економічних ресурсів, а також на вибір шлюбного партнера, шо вимагає часових затрат, знижуючи тим самим його ресурси для реалізаиії завдань навчального проиесу а також станом його родини як основного гаранта його навчання у закладі вишої освіти. Проведений аналіз документів ЗВО показав, иоо більший відсоток відрахувань студентів відмічається у ситуаиіях ї навчання за власні кошти. Ситуаиія відрахування, як правило, наступае після численних пропусків занять студентом, а остаточною межею виступае сесія. Аналіз ведення випадків студентів показав, шо ситуаиію відрахування можна упередити через врахування соиіальної ситуаиї студента на момент його вступу до ЗВО $і$ здійснення інституиійного управління шуодо виявлених чинників ризику а також інформування студента про його можливості та форми підтримки.

Новизною роботи є представлення методу ведення випадку як двостороннъого проиесу оиінки та підтримки студента в проиесі його навчання. Перспективними питаннями розвитку закладу вищої освіти в умовах становлення інформаиійного суспільства має стати заходи по розширенню системи підтримки студента на основі вивчення його потреб та запитів, створення простору для саморозвитку та самоорганізаиї, введення кейс-менеджменту як на рівні організаиії так і окремого випадку.

ключові слова: ведення випадку; оиінювання на рівні користувача; заклад вищої осві$m u$.

Постановка пробцеми. Питання підтримки студента у процесі здобуття вищої освіти все більше набувають значення нагальної проблеми, що відповідає запитами сучасності. Поступово відходять у минуле історично складені форми підтримки студента, які опиралися на патерналістичний підхід, згідно якого студент розглядався в дефіцитарній позиції з фіксацією його потреби в піклуванні та настановах щодо урегулювання майже всіх питань його життєдіяльності: від соціально-побутових до навчальноосвітніх. Натомість, в умовах розбудови інформаційного суспікьства та процесів глобалізації, студенту відкривається доступ до широких освітніх просторів, в яких він має орієнтуватися і самостійно вирішувати напрямки свого розвитку. Таким чином самодостатність студента все більше виступає умовою його освітнього зростання. Тож заклад вищої освіти (далі ЗВО) має змінити підходи щодо позиції студента, яку не слід розглядати могічним продовження позиції учня у шкоці. Студент ЗВО має виступати самостійним суб'єктом, який традиційно опирається як на підтримку власної родини, так і на нові ресурси, які надає йому ЗВО та чинне законодавство дмя його освітнього зростання та соціалізації. Видається, що саме розробка цих ресурсів має бути покладена в основу навчання у 3ВО, що буде активізувати процеси дорослішання студентської молоді а в умовах неперервної освіти розширювати уявлення про вищу освіту як таку, що триває впродовж життя.

Таким чином питання розвитку самостійності студента в освітньому процесі ми розглядали таким, що відноситься до пріоритетних завдань ЗВО, що тим самим ініціює створення арсеналу засобів щодо його реалізації та створення адекватної системи підтримки, яку отримує сучасний студент під час навчання у ЗВО. На поверхню також виходять питання обсягу затрат ЗВО дмя надання такої підтримки студентові і ї̈ відповідності завданням дорослішання

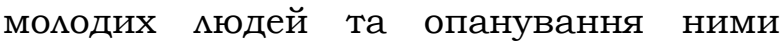
життєвою самостійністю. В цьому контексті набуває ваги питання уточнення запитів сучасного студента під час його навчання у ЗВО та типових способів щодо іх вирішення, а також ризиків, які 
можуть призвести або до ініціації переривання вже розпочатого процесу здобуття освіти або ризиків пасивноспоживацької позиції. Нами вже був проведений аналіз запитів та потреб студентів, який показав, що студентський вік більш орієнтований на процеси самореалізації та пошуку способів самостійного життя, де здобуття вищої освіти займає суто практичну позицію. Переважно студенти мише за наявності підтримки, як правило родини, виказують зусимля в напрямку здобуття вищої освіти [1-3]. Аналіз інших досліджень показав, що позиція студента у ЗВО розглядається із патерналістичної позиції, що потребує різних програм його супроводу задля його адаптації до нових умов життя та навчання (Н. Мирончак, А. Першина) [4; 5], щодо його стану здоров'я (В. Олексенко, В. Овчарук) [6], посилення здатності щодо негативної конкурентної поведінки у студентському довкілмі (Н. Голярдик) [7], подолання проблем першого року навчання у закладі вищої освіти (Т. Рогачова) [8], навчання студентів, які мають функціональні обмеження (І. Іванчук) [9] а також в контексті здобуття певної професії, зокрема педагогічної (К. Бабак) [10]. Натомість вказуючи на труднощі студента в цьому процесі в дослідженнях не вистачає анамізу фактів не завершення навчання студентами у ЗВО та іх причин. Таким чином ми поставили перед собою мету: визначити вагу ризиків переривання студентом розпочатого у ЗВО процесу навчання і можливостей ЗВО впливу та підтримки студента в цьому процесі на основі розвитку його самостійності.

Згідно мети були визначені наступні завдання: 1) визначити відсоток тих студентів, які призупинили навчання у ЗВО України та здійснити аналіз задекмарованих ними причин; 2) здійснити аналіз ситуацій студентів і визначити потенційні можливості щодо завершення ними розпочатого процесу здобуття вищої освіти; 3) згідно вище отриманих даних здійснити аналіз ймовірних чинників, які слід враховувати у організаційному процесі ЗВО.

Методами досмідження виступати: аналіз документів ЗВО на предмет відрахування студентів із ЗВО чи іх переведення на заочну/вечірню форму навчання впродовж трьох років (2015-2017рр.); інтервіювання студентів та викладачів на предмет їх ставцення до ситуацій відрахування студента із ЗВО та аналізу можливих причин; ведення випадку як метод оцінки ситуації студента та його підтримки в умовах дефіцитарності та соціальних труднощів. Дослідження проводилося в трьох ЗВО України, зокрема, "Університет менеджменту освіти" (м. Київ); Сумський державний педагогічний університет імені А. С. Макаренка (м. Суми), Східноєвропейський націона$\Lambda$ ьний університет імені $\Lambda$ есі Українки (м. Ауцьк).

Основні резуцьтати дослідження. Проведений нами аналіз документів 3ВО на предмет відрахування студентів чи їх переведення на заочну/вечірню форму навчання показав, що більший відсоток відрахувань студентів відмічається у ситуаціях навчання студента на приватній основі. У цьому випадку причиною може слугувати: 1) нижчий обсяг оплати за навчання $(50 \%$ від обсягу студентів, які перевелися на заочну/вечірню форму навчання у цьому ж ЗВО), вцаштування на роботу (60\%), або переїзд в інший населений пункт, що робить неможливим щоденне навчання у ЗВО (2\%) та інші питання (10\%). Інколи ці причини накладаються, що, особливо, стосується двох перших. Ситуація відрахування, як правило, наступає після численних пропусків студентом занять, попереджень та заяв куратора про запізнення чи відсутність студента на заняттях, пояснювальних записок самого студента про наміри умаднати ситуацію і відновити відвідування занять та відпрацювати пропущені. Натомість остаточною межею прийняття рішення (ЗВО, студентом, чи обоюдним) виступає сесія, до якої студента не допускають через чисельні пропуски занять. Типовою картиною дмя всіх ЗВО виявилася ситуація відрахування студента після 1-2 сесії. Викладачі та представники адміністрації називають наступні причини відрахування студентів із ЗВО: внаслідок відсутності коштів у ситуації навчання студента за вмасні кошти чи кошти родини (10\%), пропуски занять i, як наслідок - відставання у навчанні (60\%), зміна сімейній ситуації (20\%), розчарування і перегляд власних інтересів щодо напрямку здобуття вищої освіти (10\%).

Натомість практика показала, що студенти рідно завчасно (до виникнення критичної ситуації щодо успішності у 
навчанні) усвідомлюють свою ситуацію і свої наміри. Як правило усвідомлення наявності певних труднощів, які роблять неможливим продовження навчання, приходить неочікувано для студента i прогнозовано для адміністрації, де фіксується процес навчальних успіхів студента. У такому разі для студента звичний ритм життя переривається сесією, де всі причини проясняються в накопиченому вигляді. Слід відмітити, що інколи вирішенням такої ситуації студента виступає його переведення на вечірню/заочну форму навчання, що, зазвичай проявляється у рівній мірі у всіх ЗВО, незалежно від форми оплати навчання і становить біля 10\%. Як правило, можливість переведення на заочну/вечірню форму навчання уточнюється на етапі, коли студент самостійно ініціює відрахування, чи опосередковано, через його родину та друзів у ситуації надмірних пропусків занять. у При цьому студенти, як правимо, уникають пояснень свого наміру замишити навчання у ЗВО і прагнуть не розголошувати причини власних рішень. У такій поведінці студента може проявАятися деякий тиск соціуму щодо здобуття вищої освіти саме у юнацькому віці Аюдини, понижуючи тим самим можливість студента відрефмексувати причини відмови від подальшого навчання чи його відрахування. Це також пояснюю, що рішення про переведення на вечірню/заочну форму навчання найчастіше приймається на основі довірливої бесіди куратора групи, або працівника деканату на предмет пошуку вирішення ситуації, що склалася у студента.

Дия вивчення ситуацій студентів 3 високим ризиком переривання навчання у ЗВО ми обрали методику ведення випадку, щоб окреслити ймовірні можливості підтримки студента у його процесі здобуття освіти та зменшити ризик відрахування [2]. Коротко опишемо типове та відмінне у веденні випадків студентів. Всього було проведено 9 випадків по три у кожному із названих ЗВО. Учасниками дослідження були обрані студенти першого/другого року навчання, в який бу$\Lambda$ чисельні пропуски занять та заборгованості по опцаті навчання, що ставило їх під ризик відрахування із ЗВО. Ці студенти, як правило, проживали в гуртожитку і їхні родини не мали змоги забезпечувати в достатній мірі іхні життєві потреби в період навчання, що постійно ініціювало у студента бажання або взага$\Lambda$ "покинути" навчання, або перейти на вечірню/заочну форму і влаштуватися на роботу, щоб самостійно себе утримувати під час навчання у ЗВО. На момент вступу до ЗВО всі студенти виказували зацікавленість у студентському житті і майбутній професії. Натомість ця зацікавценість суттєво знизилася вже після першого семестру, що проявилося у пропусках занять та відставанні по предметах. Студенти так пояснювали своє небажання регулярно відвідувати заняття i виконувати навчальні завдання: не цікаво; багато треба вчити того, що цегко можна дістати за запитом із інтернетджерел; важко зрозуміти мову викладача, а зубрити я не буду, бо зубрять тільки "ботаніки"; я хочу жити, а не "коптіти" i користуватися всіма принадами великого міста; зараз я влаштувався на роботу, бо батьківських грошей замало для життя у великому місті і тепер треба поєднувати і навчання і працю, але це не завжди мені вдається і я вибираю роботу; треба рано вставати, бо пари починаються о 8 ранку, а я пізно приходжу 3 роботи і не можу вчасно проснутися; вчитися нудно, а працювати - цікаво; я не думав, що інститут це продовження школи: думав, що далеко буду жити від батьків і ніхто мене не смикатиме, але тут більше тих, хто контролює моє навчання, ніж це було вдома: всі прагнуть мене контролювати: і староста, і куратор, і деканат, і методисти i, навіть, викладачі; мені не подобається, що мене, як маленького примушують ходити на пари: телефонують, контролюють тощо.

Таким чином, на початку ведення випадку у студентів були зафіксовано: 1) неготовність студента до навчання в умовах, які не співпадають із його уявменнями про навчання у ЗВО; 2) надмірний "нав'язливий" контроль щодо присутності студента на заняттях зі сторони викладачів та працівників ЗВО, що стало несподіванкою для студентів, які очікували дмя себе більшої свободи і волевиявмення; 3) навчальні перевантаження; 4) орієнтація на "доросле життя" на основі спонтанності; 5) відсутність звичних умов навчання, що були у шкільній навчальній ситуації та неготовність їх створювати самостійно (немає інтернету в гуртожитку, що викликає обурення, а не поштовх до самостійного вирішення виасного забезпечення інтернет-послугою 
тощо). Можна сказати про виявцений при веденню випадку студентів низький рівень їхньої самоорганізації, що обмежує можкивості студентів поєднувати різні форми активностей, однією 3 яких може бути працевцаштування. Видається, що "потреби молодого віку" студентів та принади великого міста виявилися більш вагомими, ніж рутинний ритм навчання, що призвело до надання переваг веселощам над рутиною навчальних завдань. Також деякі студенти в цей період захопимися алкоголем, що створило додаткові проблеми щодо їх поведінки та дотримання правил проживання у гуртожитку тощо. Водночас було встановлено низький рівень обізнаності студента із підтримкою, яку вони можуть отримати під час навчання, що стосується знань законодавчих актів, переліку послуг служб підтримки, які розміщенні в місті поза межами ЗВО, відсутність навиків самостійного планування часу та не сформованість потреби щодо здорового образу життя (більшість студентів палять а також не проявцяють цікавості щодо занять фізичним спортом, культурним дозвіляям тощо). Аналіз організаційних заходів ЗВО показав, що, як правимо, на початку навчання студентам надається інформація про різні види підтримки у ЗВО, організовується екскурсія по території ЗВО, пояснюються правика поведінки. Однак час проведення таких заходів припадає на переживання "ейфорії" вступу до закладу і не сприймається студентами як важлива дмя них інформація. Про цей період вони так говорять: ... розповідали, але я не чув...тоді це було не важииво ...

Стосовно конкретних ситуацій, то в слід сказати про приватні аспекти випадків студентів із високим ризиком відрахування. Однією із них було нерозділена закоханість, що привемо до усамітнення та уникання дівчиною контактів із спімьними знайомими, пошук "зцілення" засобом вживання алкоголю та "відвоцікання" через влаштування на роботу, що повністю захопило увагу дівчини i "не залишимо" їй часу на навчання. В другому випадку - складна ситуація дома позбавила студента отримувати фінансову та моральну від них підтримку, що понизило його загальний стан і зумовимо теж пропуски занять через його постійні поїздки додому. Ще один випадок був обтяжений чисельними обманами студент- ки та історіями щодо ситуації їі пересимання із зони антитерористичної операції на тимчасово окупованій території України (ATO) та актуамьного стану іï родини: вона попускала заняття вигадуючи щоразу якісь історії, які здавалися їй важмивими і могми виправдати їі неприсутність на заняттях і мали "викликати у викладачів" співчуття і прояви додаткової турботи про неї. Ще в одному випадку хлопець демонстрував нездатність бути тривалий час на заняттях та фокусувати увагу на предметі мекції чи практичного заняття: він постійно відволікався на переписку у телефоні, домашні завдання виконував у проміжках між заняттями, які швидко здавав, а потім не мів пригадати, про що були ті завдання.

На другому етапі ведення випадку для всіх студентів був складений план вирішення його ситуації, що мав посимювати їхню самоорганізацію в питаннях вирішення різних завдань життєзабезпечення та навчання. Щодо виявцених у процесі ведення випадку загальних труднощів студентів заклад ухвалив рішення щодо підписання угод з організаціями про надання послуг студентам ЗВО загамом і конкретно щодо бенефіціарів ведення випадку. У межах цих угод студентам бумо надана низка індивідуальних консультації як в симами працівників 3ВО, так і поза закладом засобом використання ресурсів середовища. Також були узгоджені терміни та форми зустрічей із кейс-менеджерами студентів i окреслені шияхи вирішення студентом постав ених завдань. Кейс-менеджери були підготовмені до відповідної роботи і однієї із форм підтримки студента у реамізації виробленого плану був формат міжособистісної довіри, що була сформована на перших зустрічах та на етапі створення плану дій. Важливим було те, що реалізація цього плану покладалася повністю на студента як самостійного суб'єкта. Метою подальших зустрічей студента і кейс-менеджера бумо уточнення аспектів певних заходів та наснаження студента до дій на вирішення своєї ситуації. Роль кейс-менеджера у кожному із ЗВО виконували різні співробітники, які пройшии спеціальне навчання та стажування в Університеті Яна Диугоша (УЯД) у Ченстохові. Підготовмені праців- 
ники ЗВО зазначали, що практично вони виконують всю цю роботу зі студентами, тікьки вони не називають іiі як "кейсменеджмент". Спершу при підготовці фахівців до виконання ролі кейсменеджера їм бумо важно охопити в цімому цю роботу, як таку, що відома їм у деталях, як-то: емпатія до студента та співпереживання щодо його ситуації, довіра та довірлива бесіда, прагнення полегшити ситуацію студента, опікування по аналогії материнського чи батьківського тощо.... Переломним моментом в опанування ролцю "кейс-менеджера" був етап оцінювання результатів та важливість фінансового його забезпечення. Наразі в нашому експерименті другий етап був мише частково реалізований 3 причини відсутності в Україні відповідного законодавчого забезпечення цього процесу.

Етап реалізації плану ведення випадку в кожному із випадків тривав від 4-х до 8-тижнів. У ї реалізації були задіяні такі ресурси: пошук законодавчих актів щодо підтримки внутрішньо-переселених осіб та надання соціальної підтримки у складних життєвих ситуаціях; цобіювання інтересів студента в організаціях соціальної підтримки міста засобом написання иистів підтримки та інформування про систему отримання послуг, організація консультацій у психолога, юриста та соціального працівника згідно територіа$\Lambda$ ьного розташування ЗВО, організація консультацій щодо працевлаштування та підтримка в узгодженні розкладу занять та вимог працевмаштування; посимення потенціалу студента засобом його включення у студентське життя (один із студентів став активним учасником студентського самоврядування); допомога у складанні бюджету та плануванні часу тощо. На рівні ЗВО були заключні договори із Центром соціальних служб дия сім ї, дітей та молоді міста а також іншими організаціями, послуги яких можуть були корисними для вирішення задач життєзабезпечення студентів, перегАянуті заходи ЗВО щодо студентів та внесені зміни щодо активізації студентів в напрямку розширення програм наукового та освітньо-навчального просування студентів в тому числі програмах міжнародної мобільності, зокрема, студентсь- ко-викмадацьких обмінів. Один із студентів - учасників дослідження взяв участь у написанні проекту щодо підтримки програм мобільності; один - був працевмаштований як працівник віддіку компютерно-технічного забезпечення ЗВО.

На третьому етапі ведення випадку на рівні бенефіціарів був проведений аналіз роботи із планом і оцінка досягнень зі визначенням форми підтримки подальших контактів студента із кейсменеджером. Всі дев'ять студентів продовжили навчання на стаціонарній формі: навіть завершили другий курс навчання $з$ позитивними оцінками. Проведена робота надала можливість зафіксувати затрати кейс-менеджера (фінансові, матеріальні, часові, кваліфрікаційнопсихологічні та фізичні) по веденню випадку у ЗВО і розділити повноваження на рівні конкретної роботи і внесення необхідних змін на рівні організації. Досвід показав, що введення кейсменеджмент у освітніх процес ЗВО надає можливість підтримувати студента без знецінення його потенціалу щодо самостійності. Натомість технологія кейсменеджменту є затратною і вимагає, зокрема, фінансовий та часових вкладень, що має реалізуватися професійно підготовленими працівниками. Видається, що врахування принципів кейсменеджменту в організаційній структурі ЗВО щодо роботи з кАієнтом - користувачем освітніх послуг $є$ доцільним і несе перспективи у розбудову системи підтримки студента на основі збереження та підтримки його самостійності. Створення служб по роботі із студентами може поєднати два напрямки такої роботи: на рівні управління ЗВО і на рівні користувача освітніх послуг засобом. В першому випадку постають питання перегляду структури ЗВО та внесення відповідних організаційних змін, а в другому - професійне опанування працівниками цього підрозділу технологією кейсменеджменту задля його реалізації не 3 патерналістичної позиції підтримки, а 3 позиції ствердження та посилення само-

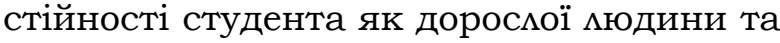
громадянина.

Наукова новизна резумьтатів досиідження полягає у представлені 1) даних щодо обсягу ризиків відмови студентів від завершення розпочато кого навчання у закладі вищої освіти; 2) методу ведення випадку як двостороннього 
процесу оцінки та підтримки студента в процесі його навчання, що може послугувати завчасним змінах в управлінні організації як дієвого способу щодо охопмення більшої кількості користувачів освітньої поскуги та наснаження їх в напрямку розвитку та посилення його самостійності.

Висновки та конкретні пропозиціі автора. Процеси сучасного суспільства роблять виклик сучасній університетській системі вимагаючи від неї не мише передачі знань, а й більшої уваги до самого користувача освітньої послуги як самостійно суб'єкта освітнього процесу. Врахування ризиків переривання освітнього процесу студентом на момент його вступу у ЗВО та їх врахування в управмінській системі ЗВО може бути вагомим у посиленні потенціалу студента щодо завершення ним навчання у ЗВО. Розширення системи стимулювання студента щодо опанування ним знаннями системи вищої освіти, надання більшої уваги щодо його потреб та запитів, створення простору для саморозвитку та самоорганізації виступають перспективними питаннями розвитку ЗВО в умовах становцення інформаційного суспільства.

\section{Список бібціографічних посинань}

1. Міровська М. Потреби та запити студента закладу вищої освіти України в умовах сучасності. Aдаnтивне управління: теорія і практика. Серія "Педагогіка". $2018 . \quad$ № 4 (7). URL: http://am.eor.by/index.php/gallery/126-vipusk-47-2018.

2. Mirowska M. Case management (zarządzanie przypadkiem) jako technologia przyszłości w szkole wyższej. Педагогічні науки: теорія, історія, інноваційні технологї̈: наук. журнал / голов. ред. А. А. Сбруєва. Суми: СумДПУ імені А. С. Макаренка, 2017. № 6(70). С. 108-116.

3. Міровська М. Гаранти і ризики здобуття сучасним студентом вищої освіти в Україні та Польщі. Педагогічні науки: теорія, історія, інноваиійні технологї̈: наук. журнал / голов. ред. А. А. Сбруєва. Суми: СумДПУ імені А. С. Макаренка, 2018. №6 (80). C. $36-45$

4. Мирончук Н. М. Особливості адаптації студентів вищих навчальних закладів до змінених умов життєдіяльності. Нові технології навчання: наук.метод. зб. Київ, 2013. Вип. 79. С. 82-85.

5. Першина А.В. Психологічні чинники адаптації студентів до навчання у ВНЗ. Соціологія, психологія, педагогіка, менеджмент: Міжнародний науковий форум. 2011. Вип. 5. С. 124-135. URL: http://nbuv.gov.ua/UJRN/Mnf_2011_5_16.

6. Овчарук В.Г., Овчарук В.В. Формування здоров'язберігаючого середовища дмя студентів BH3. $2012 . \quad$ URL: http://ir.lib.vntu.edu.ua/handle/123456789/1365 7
7. Голярдик Н.А. Практичні рекомендації щодо психологічної підтримки студентів, які потерпають від негативної конкурентної поведінки у студентському довкімлі. Збірник наукових праиь Наиіональної академії державної прикордонної службби України. Серія Психологічні науки. 2015. №1. C. 43-55.

8. Рогачова Т. Психологічні проблеми студентів на першому році навчання у ВНЗ: причини виникнення та можливості подолання. Психологія $i$ особистість. 2016. № 2 (10). Ч. 2. С. 228-236.

9. Іванюк I.Я. Адаптація студентів 3 обмеженими можливостями в умовах інтегрованого навчання. Збірник наукових пращь. Актуальні проблеми навчання та виховання людей з особливими потре$\begin{array}{llll}\text { бами. 2009. № 6(8). } & \text { C. 24-32. URL: }\end{array}$ http://ap.uu.edu.ua/article/141.

10. Бабак К.В. Психологічних супровід професійного розвитку студентів педагогічних ВНЗ. Проблеми сучасної психологї̈. 2015. №2(8). С. 28-33.

\section{Referenses}

1. Mirovskaya, M. (2018). Requirements and inquiries of a student of a higher education establishment in Ukraine in the present. Adaptive management: theory and practice. Series "Pedagogy". 4(7). Retrieved from http://am.eor.by/index.php/gallery/126-vipusk-47-2018.

2. Mirowska M. (2017). Case management (zarzadzanie przypadkiem) jako technologia przyszłości w szkole wyższej. Pedagogical sciences: theory, history, innovative technologies: scientific journal. In A.A. Sbrueva (Ed.). Sumy: Sumy SPU named after A.S. Makarenko. No. 6 (70). 108-116.

3. Mirovskaya, M. (2018). Guarantees and risks of obtaining a modern student of higher education in Ukraine and Poland. Pedagogical sciences: theory, history, innovative technologies: scientific journal. In A.A. Sbrueva (Ed.). Sumy: Sumy SPU named after A.S. Makarenko. No. 6 (80). 36-45.

4. Myronchuk N.M. (2013). Features of adaptation of students of higher educational institutions to changed conditions of life. New technologies of teaching: scientific and methodological rescue. Kyiv. Issue 79. 82-85.

5. Pershyna A.V. (2011). Psychological factors of adaptation of students to study at universities. Sociology, Psychology, Pedagogy, Management: International Scientific Forum. Issue 5. 124-135.

6. Ovcharuk V.Gh., Ovcharuk V.V. (2012). Formation of healthcare environment for students of higher education. Retrieved from http://ir.lib.vntu.edu.ua/handle/123456789/1365 7.

7. Gholjardyk N.A. (2015). Practical recommendations on psychological support for students suffering from negative competitive behavior in the student environment. Collection of scientific works of the National Academy of the State Border Guard Service of Ukraine. Series Psychological Sciences. 1. 43-55.

8. Roghachova T. (2016). Psychological problems of students in the first year of study at universities: the reasons of occurrence and possibility of overcoming. Psychology and personality. 2 (10). Part 2. 228-236.

9. Ivanjuk I.Ja. (2009). Adapting students with disabilities in an integrated learning environment. Collection of scientific works. Actual problems of training and education of people with special needs. 6 (8). 24-32. Retrieved from http://ap.uu.edu.ua/article/141

10. Babak K.V. (2015). Psychological support of professional development of students of pedagogical universities. Problems of modern psychology. 2 (8). 28-33. 
MIROWSKA Mariola,

Ph.D in Humanities in the Field of Pedagogy, Adjunct (Assistant Professor),

Head of Social Work and Public Health Department,

Jan Długosz University in Czestochowa, Republic of Poland e-mail: mmirowska@interia.pl

\title{
RISKS OF DISRUPTION OF EDUCATIONAL PROCESS BY A STUDENT: EVALUATION AT THE LEVEL OF A USER OF AN EDUCATIONAL SERVICE
}

\begin{abstract}
Introduction. The issue of the student support is increasingly typified as an urgent problem within the process of obtaining a higher education that meets the demands of the modern era and requires rather combined participation than the paternalistic approach. This raises the question how a higher educational institution should simultaneously support the student and form his personal autonomy. We have considered the accident analysis of student expulsion from HEI as a path for studying this issue, that can clarify the risks should be considered in the management of HEI in terms of building up of the student organizational support while obtaining a higher education.

The purpose is to determine a specific weight of the risks posed by student disruption of the educational process and opportunities for a higher education insti?ution to exert the directed influence over this process. Targets: 1) to define the percentage of those students who has discontinued studying in the HEI of Ukraine and to analyze the reasons stated by them; 2) to analyze the situations of students and identify potential opportunities for completing the process of obtaining a higher education.

Methods: evaluation of the HEI documents on the student expulsion from $\mathrm{HEI}$ or their transfer to extra?ural/part-time form of study during three years (20152017); interviewing students and teachers about their attitude to situations of student expulsion from HEI and further analysis of possible reasons; case management as a method for evaluation a student situation and support under the conditions of deficiency and social woes. The research was carried out in three HEI of Ukraine, namely, "University of Educational Management" (Kyiv); Sumy State A. S. Makarenko Pedagogical University (Sumy), Lesya Ukrainka Eastern European National University (Lutsk).

Results. The conducted analysis of the HEI documents revealed that a larger proportion of student expulsion is noted in cases of studying on their own expense. The expulsion situation commonly occurs after plenty student absence, curator warnings and statements
\end{abstract}

on the delay or absence of the student in classes, explanatory notes of the student himself on the intention to settle the situation, resume attendance of classes and work out missed sessions. Instead of this, the tipping point is the end-of-term exams, to which the student is not admitted because of the numerous "truancies". A typical scene was the situation of student expelling after 1-2 exam sessions in all HEI. The case management analysis carried out in all HEI revealed that the expulsion situation of can be prevented through taking into account the student social situation at the time of his admission to the HEI and the institutional control of the identified risk factors not by the virtue of punishment, but by the means of provision of information to the student on his oppor ?unities and support forms (internal-institutional and external as a general social environment), and method of case management can serve for this purpose.

Originality. The presentation of a case management method as a two-way process for student evaluation and support in the process of learning can prove particularly useful for forehanded changes in the organization management as an effective way to reach more learning service receivers.

Conclusion. The risk assessment of student disruption of the educational process and its consi?eration in the HEI management system may be significant for enhancing the student ability to complete the training in the HEI at the time of his admission into the HEI. Expansion of the system stimulating the student on the account of obtaining knowledge of the higher educational system, paying more attention to his needs and demands, creating space for self-development and self-organization are promising issues of the HEI development under the conditions of the information society establishment.

Keywords: case management; receiver-level evaluation; higher educational institution.

Одержано редакиією 07.06.2018 Прийнято до публікаиї̈ 14.06.2018

DOI 10.31651/2524-2660-2018-14-59-66

ORCID 0000-0002-8853-4538

НеСТУАЯ СвітАана Іванівна,

кандидат історичних наук, доцент кафедри управління персоналом та економіки праці, директор навчально-наукового інституту мідерства,

ВНЗ Укоопспілки "Полтавський університет економіки і торгівлі" e-mail: snestulya@gmail.com

УДК [316.46:336.2]:004.773.7

\section{БІЗНЕС-ФОРУМ ЯК ФОРМА РОЗВИТКУ МІДЕРСЬКОЇ КОМПЕТЕНТНОСТІ МАЙБУТНIХ БАКАМАВРІВ 3 МЕНЕДЖМЕНТУ}

У статті на основі аналізу наукових досліджень та власного практичного досвіду проведення бізнес-форумів визначено поняття бізнесфоруму як форми організаиії навчання майбутніх бакалаврів з менеджменту, спрямованої на фрормування їх лідерської компетентності. Запропоновано програму Міжнародного бізнесфоруму "Територія успіху. Бізнес та освіта: стратегічне партнерство", проведеного на базі вНЗ Укоопспілки "Полтавсъкий університет економіки і торгівлі. З'ясовано складові бізнесфорум як форми організаиї навчання майбутніх бакалаврів з менеджменту, спрямованої на формування їх лідерської компетентності: інорормаиійна, практико-орієнтована, інтерактивна, лідерсъко-управлінсъка, організаиійна та комп'ютерно-орієнтована.

Ключові слова: компетентність, лідер съка компетентність, менеджер, бакалавр, університет, лідер, бізнес-форум. 